The Bangladesh Veterinarian (2017) 34(2): 71- 78

\title{
Supplementation of spirulina (Spirulina platensis) on yolk colour, egg quality and production performance of laying hens
}

\author{
M Ahammed*, S Sharmin, A Khatun and KMS Islam ${ }^{1}$ \\ Department of Poultry Science, Faculty of Animal Husbandry, Bangladesh Agricultural \\ University, Mymensingh-2202, Bangladesh
}

\begin{abstract}
A total of 96 Shaver 579 laying hens of 78 weeks of age were studied for the effects on egg production of dietary supplementation with spirulina (Spirulina platensis). The hens were divided into four dietary treatments with six replications of four birds in each group. Birds of three groups were supplemented with $0.1 \%, 0.2 \%$ and $0.3 \%$ spirulina and one group was kept as control. Yolk colour significantly improved $(\mathrm{P}<0.01)$ as compared to control, without affecting any other production performances. It is suggested that dietary supplementation of spirulina at 0.2 to $0.3 \%$ levels in aged laying hens enhanced egg yolk colour. (Bangl. vet. 2017. Vol. 34, No. 2, 71-78)
\end{abstract}

\section{Introduction}

Organic feeding in poultry is pricier but organic products are safer than conventional poultry products (Blair, 2008). Algae are used in organic poultry production, having high nutritional value (Gerrard et al., 2015). Two types of algae are widely used in poultry diet. Microscopic algae are blue-green algae, which have the ability to grow under different environmental conditions and are a source of carbohydrates, proteins, amino acids, lipids, vitamins A, B (especially $\mathrm{B}_{12}$ ) and C, and colourants (Al-Harthi and El-Deek, 2012). They also increase carotene, lutein and zeaxanthin content (Athukarala et al., 2006). Spirulina platensis is ablue-green algae with antimicrobial, antiviral, anti-inflammatory and hypocholesterole micactivities (Mayada Farag et al., 2016). Spirulina platensis also enhances immune function by increasing antigen processing and T-cell activity (Qureshi et al., 1994). In addition, spirulina is a source of carotenoids, which colour yolks (Lorenz, 2003).

Egg quality, which is important for producers and consumers, is determined by the age of hens, egg storage temperature, humidity, laying season and feeding. Yolk colour, texture, firmness and smell are the main determinants of yolk quality. Yolk colour can be increased by incorporating carotenes and xanthophylls (Nys, 2000). Xanthophyll is a plant pigment, which does not affect taste but meets market demand. Natural or synthetic xanthophylls can be incorporated in layer diet. Excess pigment in diet causes orange-red yolks (Coutts and Wilson, 1990) while low doses cause olive or salmon coloured yolks (Beyer, 2005). Most people prefer golden yellow to orange

\footnotetext{
1Department of Animal Nutrition, Faculty of Animal Husbandry, Bangladesh Agricultural University, Mymensingh-2202, Bangladesh

*Corresponding author:- E-mail: musabbir.bau@gmail.com
} 
yolks. Consumers believe that eggs with pale yolks are neither tasty nor nutritious. Layer birds need to be fed pigment. The study was undertaken to determine the optimal levels of dietary S. platensis to improve egg yolk colour, egg quality and production of laying hens aged 78 - 84 weeks.

\section{Materials and Methods}

\section{Experimental birds and management}

A total of 96 Shaver 579 laying hens at 78 weeks of age were separated and kept in an open-sided house with routine management at Bangladesh Agricultural University (BAU) Poultry Farm, Mymensingh. The hens were divided into four groups and each group was divided into six sub-groups, each containing four birds. First group was control without supplementation and the other three groups were supplemented with $0.1 \%, 0.2 \%$ and $0.3 \%$ spirulina (Spirulina platensis), respectively. The trial lasted seven weeks. The bird shed was cleaned and disinfected. All feeders and drinkers were attached in the three tier California cage system. The experimental cage was divided into 24 equal sections, each containing four hens. Strict hygiene and bio-security were followed. A digital thermo-hygrometer was used to maintain the poultry shed temperature and relative humidity.

\section{Preparation of experimental diets}

A corn-soybean meal-based diet was formulated with local ingredients to meet the nutrient requirements of the hens (Table 1). Processed spirulina powder was collected from June Pharmaceuticals Ltd. Myanmar (Table 2) and was mixed thoroughly into the basal diet according to experimental layout.

Table 1: Ingredients and composition of basal diet

\begin{tabular}{lccc}
\hline \multicolumn{1}{c}{ Feed ingredients } & Basal diet (amounts in $\mathrm{kg})$ & \multicolumn{2}{c}{ Chemical composition $(\%)$} \\
\hline Maize & 58 & ME (Kcal $/ \mathrm{kg})$ & 2809.2 \\
Protein concentrate & 4 & $\mathrm{CP}$ & 17.57 \\
Soya meal & 23 & $\mathrm{Ca}$ & 3.77 \\
Limestone & 9 & Total P & 0.77 \\
DCP & 2 & Av. P & 0.47 \\
Soybean oil & 3 & Lysine & 0.91 \\
Vit-Min Premix & 0.25 & Methionine & 0.45 \\
Lysine & 0.04 & Tryptophan & 0.45 \\
Methionine & 0.15 & & \\
Enzyme & 0.04 & & \\
Salt & 0.52 & & \\
\hline
\end{tabular}

$\mathrm{DCP}=$ Di-calcium phosphate; Vit-Min Premix $=$ Vitamin-Mineral premix $; \mathrm{CP}=$ Crude protein $; \mathrm{Ca}=$ Calcium; $\mathrm{P}=$ Phosphorus; $\mathrm{ME}=$ Metabolizable energy 
Table 2: Chemical composition of Spirulina platensis

\begin{tabular}{l|c|c|c}
\hline \multicolumn{1}{c|}{ General composition } & $\%$ & Phytopigments & Mg 100 g-1 \\
\hline Protein & $55-59$ & Total carotenoids & $400-500$ \\
Carbohydrates & $15-25$ & Carotenes & $160-260$ \\
Fats (Lipids) & $5-6$ & Xanthophyll & $170-240$ \\
Minerals (Ash) & $6-9$ & Chlorophyll & $1300-1700$ \\
Moisture & $2.5-4.5$ & Phycocyanin & $15000-19000$ \\
\hline
\end{tabular}

\section{Data collection}

Hen day egg production (HDEP), egg weight and egg mass outputs were recorded. Two eggs from each sub-group were collected. The egg shape index, shell thickness and shell percentage were measured. The albumen index, Haugh unit, yolk index and yolk colour score were measured. The length and width were measured with the help of slide callipers for determining the shape index. Shell thickness was measured by means of an eggshell thickness meter (Ogawa Seiki Company, Tokyo, Japan). Yolk Index was calculated by the ratio of yolk height and yolk width. The Haugh unit was calculated by the formula suggested by Haugh (1937). Yolk colour score was determined by comparing with the Roche Yolk colour fan (RYC, F. Hoffman-La Roche and Ltd., Switzerland) depending on visual comparison according to Vuilleumier (1969). Best yolk colour was observed by Chromameter that represents L* (lightness), $\mathrm{a}^{*}$ (redness) and $\mathrm{b}^{*}$ (yellowness) values (Fig. 1). In a uniform colour scale, the differences between points plotted in the colour space correspond to visual differences between the colours plotted.

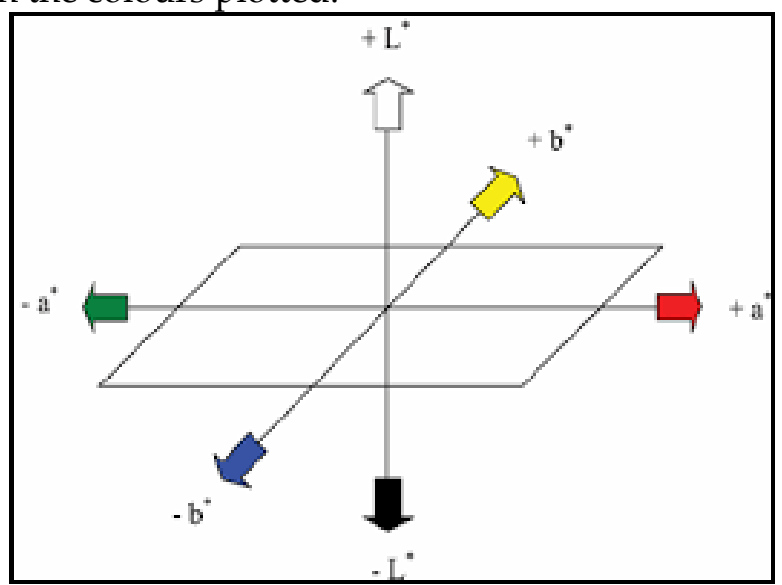

Fig. 1: $L^{*}, a^{*}, b^{*}$ values on egg yolk colour space.

\section{Statistical analysis}

Data were subjected to analysis of variance (ANOVA) in a completely randomized design (CRD) employing SAS (2002) statistical computer package program. The least significant differences (LSD) were calculated to compare treatment means. 


\section{Results and Discussion}

\section{Egg production performance}

No differences in the hen day egg production (HDEP) were caused by the addition of spirulina (Table 3). This result is consistent with the result of other researchers (Garcia et al., 2002; Zahroojian et al., 2011) where they reported that dietary marine algae supplementation had no effect on egg production. Halle et al. (2009) observed the same at different levels of addition of algae. On the other hand, Nikodémusz et al. (2010); Mariey et al. (2012) found significantly better HDEP after supplementation of spirulina-containing diet in laying hens which are not in agreement with present finding.

Table 3: Egg production of hens fed spirulina-supplemented diet at 78-84 weeks of age

\begin{tabular}{|c|c|c|c|c|c|c|c|c|}
\hline \multirow[t]{2}{*}{ Parameters } & \multirow[t]{2}{*}{ Treatments } & \multicolumn{7}{|c|}{ Age (week) } \\
\hline & & $1^{\text {st }}$ & $2^{\text {nd }}$ & $3^{\text {rd }}$ & $4^{\text {th }}$ & $5^{\text {th }}$ & $6^{\text {th }}$ & 7th \\
\hline \multirow{5}{*}{ 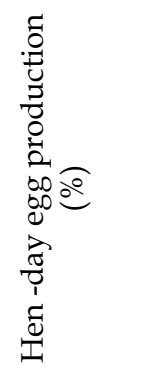 } & Control & $71.4 \pm 6.1$ & $86.9 \pm 7.0$ & $89.3 \pm 4.4$ & $84.5 \pm 4.3$ & $80.9 \pm 4.8$ & $85.7 \pm 2.6$ & $82.1 \pm 3.1$ \\
\hline & $\begin{array}{c}0.1 \% \\
\text { Spirulina }\end{array}$ & $72.6 \pm 4.3$ & $89.3 \pm 3.1$ & $85.7 \pm 3.2$ & $85.7 \pm 1.8$ & $83.3 \pm 5.1$ & $79.8 \pm 3.9$ & $79.8 \pm 4.3$ \\
\hline & $\begin{array}{c}0.2 \% \\
\text { Spirulina }\end{array}$ & $77.4 \pm 5.9$ & $86.9 \pm 7.7$ & $89.3 \pm 5.5$ & $82.1 \pm 5.5$ & $80.9 \pm 6.6$ & $85.7 \pm 4.5$ & $80.9 \pm 6.8$ \\
\hline & $\begin{array}{c}0.3 \% \\
\text { Spirulina }\end{array}$ & $78.6 \pm 8.7$ & $85.7 \pm 7.6$ & $83.3 \pm 8.4$ & $86.9 \pm 4.7$ & $80.9 \pm 3.5$ & $79.8 \pm 6.5$ & $82.1 \pm 7.9$ \\
\hline & P-Value & NS & NS & NS & NS & NS & NS & NS \\
\hline
\end{tabular}

NS $=$ No significant, Mean \pm SE

\section{Egg quality parameters}

Egg weight and egg mass output data are shown in Table 4. There was similar egg weight found among the dietary treatments. In other studies, spirulina-supplemented diet increased egg weight (Sakaida Takashi, 2003; Nikodémusz et al., 2010). Ross et al. (1994) found that egg weight was significantly higher that containing increased levels of spirulina, which are in agreement with our findings at the end of $3^{\text {rd }}$ week but at the end of $7^{\text {th }}$ week egg weight was almost similar among different spirulina levels.

No differences were observed on egg mass, yolk weight, percent shell and Haugh unit after supplementation of spirulina. It has been reported that the egg weight and yolk weight were reduced significantly by dietary inclusion of higher level $(4.8 \%)$ of marine algae (Al-Harthiand El-Deek, 2012). There was no effect of spirulina in layer diet on the shape index, shell thickness and shell percentage of egg. Inborr (1998) and Mariey et al. (2012) reported that spirulina had no effect on eggshell percentage, similar to our results. Spirulina had no influence on albumen index and Haugh Unit up to the end of $7^{\text {th }}$ week. 
Table 4: Egg weight and egg mass output of laying hens fed Spirulina-supplemented diet at 78-84 weeks of age

\begin{tabular}{|c|c|c|c|c|c|c|c|c|}
\hline \multirow{2}{*}{$\begin{array}{l}\text { Para- } \\
\text { meters }\end{array}$} & \multirow{2}{*}{$\begin{array}{l}\text { Treat- } \\
\text { ments }\end{array}$} & \multicolumn{7}{|c|}{ Age (week) } \\
\hline & & $1^{\text {st }}$ & $2^{\text {nd }}$ & $3^{\text {rd }}$ & $4^{\text {th }}$ & $5^{\text {th }}$ & $6^{\text {th }}$ & $7^{\text {th }}$ \\
\hline \multirow{5}{*}{ 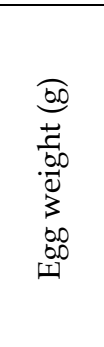 } & Control & $65.7 \pm 3.1$ & $63.6 \pm 1.7$ & $61.6^{b} \pm 1.7$ & $65.4 \pm 1.7$ & $63.8 \pm 1.8$ & $64.4 \pm 2.4$ & $69.0 \pm 2.8$ \\
\hline & $\begin{array}{l}0.1 \% \\
\text { Spirulina }\end{array}$ & $66.2 \pm 2.9$ & $65.1 \pm 1.5$ & $63.4^{\mathrm{ab}} \pm 1.8$ & $64.2 \pm 1.3$ & $62.6 \pm 2.7$ & $65.9 \pm 2.8$ & $67.1 \pm 2.3$ \\
\hline & $\begin{array}{l}0.2 \% \\
\text { Spirulina }\end{array}$ & $67.8 \pm 2.3$ & $67.4 \pm 1.0$ & $67.3^{a} \pm 2.3$ & $66.1 \pm 2.0$ & $65.7 \pm 2.8$ & $68.0 \pm 3.0$ & $68.7 \pm 3.7$ \\
\hline & $\begin{array}{l}0.3 \% \\
\text { Spirulina }\end{array}$ & $67.8 \pm 5.9$ & $66.7 \pm 2.7$ & $68.5^{a} \pm 1.3$ & $65.7 \pm 1.9$ & $64.5 \pm 2.2$ & $67.5 \pm 3.3$ & $69.7 \pm 3.1$ \\
\hline & P-Value & NS & NS & * & NS & NS & NS & NS \\
\hline \multirow{5}{*}{ 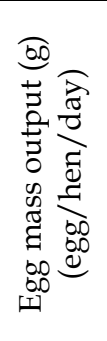 } & Control & $46.3 \pm 3.2$ & $54.1 \pm 3.4$ & $55.7 \pm 2.8$ & $55.8 \pm 1.5$ & $49.8 \pm 2.3$ & $52.5 \pm 0.9$ & $56.3 \pm 0.7$ \\
\hline & $\begin{array}{l}0.1 \% \\
\text { Spirulina }\end{array}$ & $49.1 \pm 2.4$ & $58.1 \pm 1.3$ & $52.8 \pm 3.1$ & $53.1 \pm 0.7$ & $49.4 \pm 1.9$ & $50.9 \pm 2.6$ & $53.9 \pm 1.4$ \\
\hline & $\begin{array}{l}0.2 \% \\
\text { Spirulina }\end{array}$ & $52.1 \pm 3.6$ & $53.5 \pm 4.9$ & $58.1 \pm 5.4$ & $52.9 \pm 1.6$ & $51.3 \pm 2.6$ & $57.5 \pm 2.9$ & $55.8 \pm 3.2$ \\
\hline & $\begin{array}{l}0.3 \% \\
\text { Spirulina }\end{array}$ & $52.7 \pm 4.3$ & $55.8 \pm 4.8$ & $54.7 \pm 6.2$ & $56.4 \pm 1.4$ & $51.7 \pm 2.7$ & $52.5 \pm 2.9$ & $56.2 \pm 4.5$ \\
\hline & P-Value & NS & NS & NS & NS & NS & NS & NS \\
\hline
\end{tabular}

NS = Not significant; Mean $\pm \mathrm{SE} ;{ }^{*}=\mathrm{P}<0.05 ; \mathrm{a}, \mathrm{b}, \mathrm{c}=$ means bearing dissimilar superscript in $\mathrm{a}$ column differ significantly

\section{Yolk index and yolk colour}

Yolk index and yolk colour score data are presented in Table 5. Yolk index was not affected by addition of spirulina in layer diet. This result is consisted with Zahroojian et al. (2013) who found no significant variation of yolk index after dietary supplementation of spirulina. All groups showed similar results in yolk colour score up to $2^{\text {nd }}$ week of feeding trial. At $4^{\text {th }}$ week of production, the maximum yolk colour score $(7.50)$ was found in $0.3 \%$ spirulina group and it was significant $(\mathrm{P}<0.01)$ when compared with control group. There was a strong positive correlation between the inclusion of spirulina supplementation and egg yolk colour at the end of 4th week. Spirulina-containing diet enhanced the yolk colour scores of egg yolks of hens by RYCF and Chromameter. In general, the yolk colour score depends on the levels of natural pigments, mainly xanthophyll and canthaxanthin in the diet and the type and ratio of these compounds. Enhancement of yolk colour score is supported by several workers (Ross et al., 1994; Mariey et al., 2012) who observed that spirulinasupplemented diet significantly increased yolk colour score.

Table 6 represents the colour of the yolk. Yellowness was indicated by $b^{*}$ values. The $0.3 \%$ spirulina group was significantly more yellow $(\mathrm{P}<0.05)$ than the control group. Negative $a^{*}$ values indicated greenish colour, and $L^{*}$ indicates lightness (+ white, - black) of yolk, which were not significantly different between groups. Similar results were reported by Herber-McNeill and Van-Elswyk, 1998. Zeller et al. (2001) pointed 
out that Schizochytrium sp. algae contained carotenoids, specifically canthaxanthin and beta-carotene, which are major sources for yolk pigmentation.

Table 5: Yolk index and yolk colour of the eggs of laying hens fed spirulinasupplemented diet at 78-84 weeks of age

\begin{tabular}{|c|c|c|c|c|c|c|c|c|}
\hline \multirow{2}{*}{$\begin{array}{c}\text { Para- } \\
\text { meters }\end{array}$} & \multirow{2}{*}{$\begin{array}{l}\text { Treat- } \\
\text { ments }\end{array}$} & \multicolumn{7}{|c|}{ Age (week) } \\
\hline & & $1^{\text {st }}$ & $2^{\text {nd }}$ & $3^{\text {rd }}$ & $4^{\text {th }}$ & $5^{\text {th }}$ & $6^{\text {th }}$ & $7^{\text {th }}$ \\
\hline \multirow{5}{*}{ 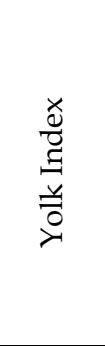 } & Control & $39 \pm 0.0$ & $40 \pm 0.0$ & $0.41 \pm 0.0$ & $0.40 \pm 0.0$ & $0.42 \pm 0.0$ & $0.40 \pm 0.0$ & $0.40 \pm 0.0$ \\
\hline & $\begin{array}{l}0.1 \% \\
\text { Spirulina }\end{array}$ & $9 \pm 0.0$ & $0.40 \pm 0.0$ & $0.40 \pm 0.0$ & $0.41 \pm$ & $0.40 \pm 0.0$ & $0.41 \pm 0.0$ & $0.40 \pm 0.0$ \\
\hline & $\begin{array}{l}0.2 \% \\
\text { Spirulina }\end{array}$ & $0.39 \pm 0.0$ & $0.40 \pm 0.0$ & $0.41 \pm 0.0$ & $0.40 \pm$ & $0.40 \pm 0.0$ & $0.40 \pm 0.0$ & $0.41 \pm 0.0$ \\
\hline & $\begin{array}{l}0.3 \% \\
\text { Spiru lina }\end{array}$ & $0.40 \pm 0.0$ & $0.40 \pm 0.0$ & $0.40 \pm-0.0$ & $0.40 \pm 0.0$ & $0.42 \pm 0.0$ & $0.42 \pm 0.0$ & $0.40 \pm 0.0$ \\
\hline & P-Value & NS & NS & NS & NS & NS & NS & NS \\
\hline \multirow{5}{*}{ 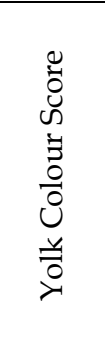 } & Control & $6.33 \pm 0.2$ & $6.50 \pm 0.4$ & $6.50 \mathrm{~b} \pm 0.2$ & $6.67 b \pm 0.3$ & $6.83 \mathrm{ab} \pm 0.2$ & $6.50^{b} \pm 0.2$ & $6.50 \pm 1.1$ \\
\hline & $\begin{array}{l}0.1 \% \\
\text { Spirulina }\end{array}$ & $6.83 \pm 0.2$ & $6.50 \pm 0.2$ & $7.50^{a} \pm 0.2$ & $7.00^{a b} \pm 0.1$ & $7.00^{a b} \pm 0.1$ & $6.83^{a b} \pm 0.1$ & $6.83 \pm 0.3$ \\
\hline & $\begin{array}{l}0.2 \% \\
\text { Spirulina }\end{array}$ & $6.17 \pm 0.3$ & $6.67 \pm 0.2$ & $7.33 \mathrm{ab} \pm 0.2$ & $7.33 a b \pm 0.1$ & $7.33 a \pm 0.1$ & $6.67 \mathrm{ab} \pm 0.1$ & $7.00 \pm 0.2$ \\
\hline & $\begin{array}{l}0.3 \% \\
\text { Spirulina }\end{array}$ & $6.67 \pm 0.2$ & $7.17 \pm 0.3$ & $7.17 \mathrm{ab} \pm 0.2$ & $7.50^{a} \pm 0.1$ & $7.33^{a} \pm 0.1$ & $7.00^{a} \pm 0.0$ & $7.50 \pm 0.5$ \\
\hline & P-Value & NS & NS & * & ** & * & * & NS \\
\hline
\end{tabular}

NS $=$ No significant, Mean $\pm \mathrm{SE} ;{ }^{*}=\mathrm{P}<0.05,{ }^{*}=\mathrm{P}<0.01, \mathrm{a}, \mathrm{b}, \mathrm{c}=$ means bearing dissimilar superscript in a column differ significantly

Table 6: Yolk colour score by chromameter of laying hens fed spirulina-supplemented diet at 78-84 weeks of age

\begin{tabular}{l|cccccc}
\hline Parameter & \multicolumn{4}{|c|}{ Dietary treatment } & \multirow{2}{*}{ P-value } \\
\cline { 2 - 5 } & Control & $0.1 \%$ Spirulina & $0.2 \%$ Spirulina & $0.3 \%$ Spirulina & \\
\hline $\mathrm{L}^{*}$ & $35.67 \pm 1.5$ & $35.68 \pm 2.2$ & $36.07 \pm 1.5$ & $38.93 \pm 1.2$ & NS \\
$\mathrm{a}^{*}$ & $-1.28 \pm 0.1$ & $-1.42 \pm 0.2$ & $-1.45 \pm 0.1$ & $-1.53 \pm 0.1$ & NS \\
$\mathrm{b}^{*}$ & $16.64^{\mathrm{bc}} \pm 0.6$ & $16.78^{\mathrm{bc}} \pm 0.4$ & $17.38^{\mathrm{b}} \pm 0.6$ & $19.20^{\mathrm{a}} \pm 0.9$ & $*$ \\
\hline
\end{tabular}

$\mathrm{L}^{*}$ (lightness), $\mathrm{a}^{*}$ (redness), $\mathrm{b}^{*}$ (yellowness) of yolk colour, NS $=$ No significant, Mean $\pm \mathrm{SE}$; ${ }^{*}=$ $\mathrm{P}<0.05 \mathrm{a}, \mathrm{b}, \mathrm{c}=$ means bearing dissimilar superscript in a row differ significantly

\section{Conclusions}

Spirulina supplementation in diet of laying hens had no detrimental effect on egg production performance and egg quality characteristics. Spirulina algae could be safely used in laying hen diets, at level of $0.3 \%$ with good effects on egg yolk colouration in aged layers. 


\section{References}

Al-Harthi MA, El-Deek AA 2012: Nutrient profiles of brown marine algae (Sargassum dentifebium) as affected by different processing methods for chicken. Journal of Food Agriculture and Environment 10 475-480.

Athukorala Y, Nam K, Jeon Y 2006: Antiproliferative and antioxidant properties of an enzymatic hydrolysate from brown alga Ecklonia cava Food Chem. Toxicology $\mathbf{4 4}$ 1065-1074.

Beyer RS 2005: Factors Affecting Egg Quality. Kansas State University. http:// www.oznet.ksu.edu/library/lvstk2/ep127.pdf.

Blair R 2008: Nutrition and Feeding of Organic Poultry. Cromwell Press Trowbridge, UK.ISBN: 9781845934064.

Coutts JA, Wilson GC 1990: Egg Quality Handbook. Queensland Department of Primary Industries, Australia.

Garcia EA, Mendes AA, Pizzolante CC, Gonçalves HC, Oliveira RP, Silva MA 2002: Effect of Cantaxantina levels on performance and egg quality of laying hens. Brazilian Journal of Poultry Science 4 1-4.

Gerrard CL, Smith J, Nelder R, Bright A, Colley M, Clements R, Pearce BD 2015: 100\% Organic Poultry Feed: Can algae replace soybean expeller in organic broiler diets? Organic Farming 1 38-45.

Halle I, Janczyk P, Freyer G, Souffrant WB 2009: Effect of microalgae chlorella vulgaris on laying hen performance. Archieve Zootechnique 12 5-13.

Haugh R 1937: The Haugh unit for measuring egg quality. US Egg Poultry Magazine 43 552-555.

Herber-McNeill SM, Van-Elswyk ME 1998: Dietary marine algae maintains egg consumer acceptability while enhancing yolk colour. Poultry Science 77 493-96.

Inborr J 1998: Haematococcus, the Poultry Pigmentor. Feed Mixture 6 31-34. doi: 10.1080/10408690590957188.

Lorenz RT 2003: A Review of Spirulina and Haematococcus algae meal as a carotenoid and vitamin supplement for poultry. http:// www.cyanotech.com/pdfs/spbul53.pdf.

Mariey YA, Samak HR, Ibrahem MA 2012: Effect of using spirulina platensis algae as a feed additive for poultry diets. 1. Productive and Reproductive Performances of Local Laying Hens. Egyptian Poultry Science 32 201-215.

Farag, MR, Alagawany M, Abd El-Hack, ME, Dhama K 2016: Nutritional and healthical aspects of spirulina (Arthrospira) for poultry, animals and human-a review. International Journal of Pharmacology 12 36-51.

Nikodémusz E, Páskai P, Tóth L, Kozák J 2010: Effect of dietary spirulina supplementation on the reproductive performance of farmed pheasants: technical articles. Institute of Animal Husbandry, SzentIstván University Gödöllo, Hungary. Poultry Industry. 
Nys Y 2000: A review on dietary carotenoids and egg yolk colouration. Archiv fur Geflugelkunde 45-54, ISSN 0003-9098. https:/ / www.researchgate.net/publication/279647522.

Park JH, Upadhaya SD, Kim IH 2015: Effect of dietary marine microalgae (Schizochytrium) powder on egg production, blood lipid profiles, egg quality, and fatty acid composition of egg yolk in layers. Asian-Australasian Journal of Animal Science 28 391-397.

Qureshi MA, Garlich D, Kidd, MT, Ali RA 1994: Immune enhancement potential of Spirulina platensis in chickens. Poultry Science 7346.

Ross E, Puapong DP, Cepeda FP, Patterson PH 1994: Comparison of freeze-dried and extruded Spirulina platensis as yolk pigmenting agents. Poultry Science 731282.

Sakaida T 2003: Effect of administration of spirulina on egg quality and egg components. Animal Husbandry 57 191-195.

SAS Institute 2002: SAS User's Guide: Statistics. Version 6.12.SAS Institute Inc., Cary, NC.

Takashi S 2003: Effect of administration of Spirulina on egg quality and egg components. Animal Husbandry 57 191-195.

Vuilleumiler JP 1969: The "Roche Yolk Colour Fan" an instrument for measuring yolk colour. Poultry Science 48 767-779.

Zahroojian N, Moravej H, Shivazad M 2011: Comparison of marine algae (Spirulina platensis) and synthetic pigment in enhancing egg yolk colour of laying hens. British Poultry Science 52 584-588.

Zahroojian N, Moravej H, Shivazad M 2013: Effects of dietary marine algae (Spirulina platensis) on egg quality and production performance of laying hens. Journal of Agricultural Science and Technology 15 1353-1360.

Zeller S, Barclay W, Abril R, Shahidi F, Finley J 2001: Production of docosahexaenoic acid from microalgae Omega-3 fatty acids: chemistry nutrition and health effects. Washington, DC, American Chemical Society pp. 108-124. 